\section{Australian Journal of \\ Crop Science}

\title{
Application of slaughterhouse residues as nitrogen source replacing commercial fertilizers on mombasa grass (Megathyrsus maximus)
}

\author{
Rubens Ribeiro da Silva ${ }^{1}$, Rubson da Costa Leite ${ }^{2^{*}}$, Jefferson Santana da Silva Carneiro ${ }^{3}$, Gilson Araújo de \\ Freitas ${ }^{1}$, Antônio Carlos Martins dos Santos ${ }^{1}$, Antonio Clementino dos Santos ${ }^{2}$, Luiz Alberto Kuyumjian ${ }^{1}$ \\ ${ }^{1}$ Federal University of Tocantins, Department of Plant Production, Gurupi-TO, Brasil \\ ${ }^{2}$ Federal University of Tocantins, Department of Tropical Animal Science, Araguaína-TO, Brasil \\ ${ }^{3}$ Federal University of Lavras, Department of Soil and Plant Nutrition, Lavras-MG, Brasil
}

*Corresponding author: rubsonif@gmail.com

\begin{abstract}
We hypothesized that the use of the residues of hull and horn flour and blood flour from the cattle slaughtering industry could provide a similar effect of nitrogen fertilizers when applied in pastures. For this reason, the objective was to evaluate the agronomic performance of mombasa grass fertilized with alternative nitrogen sources. A randomized block design in a $3 \times 4+1$ factorial scheme was used with four replications. Three sources of nitrogen were studied (hoof and horn flour, blood flour and urea) and four nitrogen doses $\left(100,200,300\right.$ and $\left.400 \mathrm{~kg} \mathrm{ha}^{-1} \mathrm{~N}\right)$, plus a control with no nitrogen application. The experimental units consisted of plastic pots with a capacity of $5.0 \mathrm{dm}^{3}$, and $4.0 \mathrm{dm}^{3}$ of soil was used. The application of the alternative sources - hull and horn flour and blood flour - promoted an increase in attributes such as leaf area, number of tillers, crude protein and forage mass. The organic sources have the potential to be applied as nitrogen sources in soils under pasture, which would promote an eco-friendly destination for these residues.
\end{abstract}

Keywords: Alternative sources, blood flour from cattle, hoof and horn flour, meatpackers, tropical forage.

Abbreviations: AEN_agronomic efficiency of nitrogen, BF_blood flour, CC_chlorophyll content, $C P$ _crude protein, FM_forage mass, HHF_hoof and horn flour, LA leaf area and NT number of tillers.

Introduction

The world cattle herd in 2016 was 1.4 billion head, and, only in Brazil, nearly 27 million animals were slaughtered. The estimates show that by 2026 this number could reach 48 million animals (ABIEC, 2017). Thus, the high rate of cattle slaughter in the country results in great amounts of generated residues (Pereira et al., 2016), which can cause environmental impacts if not properly destined.

Meatpackers and slaughterhouses are responsible for the processing and treatment of residues caused by animal slaughter, with the responsibility of avoiding incorrect disposal in the environment (Demattê et al., 2016). Transforming these residues into value-added materials such as fertilizers, specifically for pastures, allows the return of part of the nutrients extracted by cattle slaughter process to the soil.

Several studies have reported the application of alternative sources of commercial fertilizers (Demattê et al., 2016; Zwetsloot et al., 2014; Carneiro et al., 2017), and as soil corrective agents (Freitas et al., 2015). Studies showed that the use of by-products from the refrigeration industry reduces environmental impacts, promotes economic gains, maintains fertility levels, increases productivity and improves soil chemical and physical properties (Araújo et al., 2011; Carneiro et al., 2017).
Residues from slaughterhouses have large amounts of nitrogen (Bonchenari et al., 2017) and high concentration of biodegradable organic matter (Amanatidou et al., 2015). Therefore, it was hypothesized that the use of hoof and horn flour (HHF) and blood flour (BF) residues from the cattle slaughtering industry could provide a similar effect of a nitrogen fertilizer when applied to pasture.

In Brazilian soils, nitrogen fertilization is necessary, which increases production costs (Canto et al., 2016), has a shortterm effect (Hungary et al., 2016) and its majority comes from fossil fuels (Morais et al., 2012). The use of the HHF and $\mathrm{BF}$ residues generated by the cattle production industry could reduce the use of commercial fertilizer and provide an appropriate destination for these wastes. Thus, the objective of this study was to evaluate the agronomic performance of Mombasa grass fertilized with alternative nitrogen sources.

Results

Response of variables to interaction between factors

The results of the analysis of variance showed an effect of the nitrogen sources for the following variables: leaf area (LA), number of tillers (NT), crude protein (CP), agronomic 
efficiency of nitrogen (ANE) and forage mass (FM) (Fig. 1). Regarding the interaction between sources and nitrogen doses, only the chlorophyll content (CC) did not show any kind of interaction (Fig. 1C).

Leaf area (LA) did not present difference between the sources applied at doses of 100 and $400 \mathrm{~kg} \mathrm{ha}^{-1}$ of $\mathrm{N}$. However, in the intermediate doses, there was an increase as a function of the supplied source (Fig. 1A). At the dose of $200 \mathrm{~kg} \mathrm{ha}^{-1}$ of $\mathrm{N}$, urea presented a $28 \%$ reduction in LA when compared to and horn flour (HHF) and $25 \%$ in relation to blood flour (BF). At this dose, the HHF and BF sources presented similar behavior.

At the dose $300 \mathrm{~kg} \mathrm{ha-}{ }^{1}$ of $\mathrm{N}, \mathrm{BF}$ presented a similar result of $\mathrm{HHF}$, which was higher than urea. When compared to urea, $\mathrm{BF}$ promoted a $19 \%$ increase in plant LA. By comparing BF with the control treatment (without nitrogen), the increase in LA was $53 \%$.

For numbers of tillers (NT) at the dose of $100 \mathrm{~kg} \mathrm{ha}^{-1}$ of N, urea was higher than BF and similar HHF (Fig. 1B). The urea source promoted $36 \%$ of NT increments when compared to plants fertilized with BF. The BF source promoted NT similar to plants that did not receive nitrogen (19 tillers).

At the dose $200 \mathrm{~kg} \mathrm{ha}^{-1}$ of $\mathrm{N}$, urea was higher than the HHF and BF sources, promoting increases of 45 and $52 \%$, respectively. This behavior was observed for the doses 300 and $400 \mathrm{~kg} \mathrm{ha}^{-1}$, reaching an increase of up to $58 \%$ in the dose of $400 \mathrm{~kg} \mathrm{ha}^{-1}$ of $\mathrm{N}$ with urea compared to HHF.

For the chlorophyll content (CC), there was no difference between the evaluated nitrogen sources (Fig. 1C). Regardless of the source evaluated, the plants presented a CC of 26 ICF, which was $13 \%$ higher than the control plants.

The crude protein (CP) at the dose of $100 \mathrm{~kg} \mathrm{ha}^{-1}$ of $\mathrm{N}$ was higher for HHF than for the BF and urea sources, which promoted increases of 13 and 7\%, respectively (Fig. 1D). When compared to the control treatment, the HHF increment in CP was $24 \%$.

At the dose $200 \mathrm{~kg} \mathrm{ha}^{-1}$ of $\mathrm{N}$, there was no difference between the evaluated sources, producing an average $\mathrm{CP}$ of $8.85 \%$. In the dose $300 \mathrm{~kg} \mathrm{ha}^{-1}$ of $\mathrm{N}$, the BF source was higher than HHF (increase of $16 \%$ in CP) and was similar the urea (mean CP of $10 \%$ ).

At the dose $400 \mathrm{~kg} \mathrm{ha}^{-1}$ of $\mathrm{N}$, the plants that received cover urea application presented higher $\mathrm{CP}$ value than the plants that received the HHF and BF sources (increase in $\mathrm{CP}$ of 34 and $15 \%$, respectively). The BF source presented the second highest evaluated $C P$ value, with a value $16 \%$ higher than the HHF source.

For the agronomic efficiency of nitrogen (AEN) at the dose $100 \mathrm{~kg} \mathrm{ha}^{-1}$ of $\mathrm{N}$, urea was higher than HHF (up to $71 \%$ ) and like BF (Fig. 1E). The HHF source, although inferior to urea, was similar to $\mathrm{BF}$.

At the dose $200 \mathrm{~kg} \mathrm{ha}^{-1}$ of $\mathrm{N}$, urea remained higher than $\mathrm{HHF}$ and similar to BF; and the BF source differed from HHF, presenting an increase of $152 \%$. With the reduction in $A E N$ values (Fig. 1E) as a function of the increase in $\mathrm{N}$ doses ( 300 and $400 \mathrm{~kg} \mathrm{ha}^{-1}$ ), the sources presented similar AEN values, varying from 1.49 to 2.75 . Regarding the forage mass (FM) of the mombasa grass plants at the dose $100 \mathrm{~kg} \mathrm{ha}^{-1}$ of $\mathrm{N}$, the HHF source was higher than BF and similar to urea (Fig. 1F). The HHF source presented FM $70 \%$ higher than $B F$, while urea produced $\mathrm{FM} 44 \%$ higher than $\mathrm{BF}$.

At the doses $200 \mathrm{~kg} \mathrm{ha}^{-1}$ and $300 \mathrm{~kg} \mathrm{ha}^{-1}$ of $\mathrm{N}$, the plants presented similar production, independently of the used nitrogen source. For the $200 \mathrm{~kg} \mathrm{ha}^{-1}$ of $\mathrm{N}$ dose, the mean FM of the sources was $3.7 \mathrm{~g} \mathrm{pot}^{-1}$. At the dose $300 \mathrm{~kg} \mathrm{ha}^{-1}$ of $\mathrm{N}$, the mean FM value was $4.6 \mathrm{~g} \mathrm{pot}^{-1}$.

For the dose $400 \mathrm{~kg} \mathrm{ha}^{-1}$ of $\mathrm{N}$, the urea source was higher than the alternative tested sources (Fig. 1F). When compared to $\mathrm{HHF}$, the increment with urea use was $31 \%$ in $\mathrm{FM}$; in relation to $\mathrm{BF}$ this increase corresponded to $87 \%$. The alternative sources did not show any difference at this dose.

\section{Response to Nitrogen doses}

Regarding the nitrogen sources at the applied doses, it was possible to determine the appropriate dose for each evaluated source (Fig. 2). For the LA variable, the HHF source presented an adjustment to the linear positive model as a function of the applied doses (Fig. 2A), with plants producing LA of $0.06 \mathrm{~cm}^{2}$ to each kilo of applied nitrogen, with a production of $99.3 \mathrm{~cm}^{2}$ at the dose $400 \mathrm{~kg} \mathrm{ha}^{-1}$. The BF source had maximum LA production $\left(103.5 \mathrm{~cm}^{2}\right)$ at the maximum efficiency dose of $287 \mathrm{~kg} \mathrm{ha}^{-1}$ of $\mathrm{N}$. The urea source had no adjustment to the regression model, with mean LA of $92.4 \mathrm{~cm}^{2}$.

Comparing the LA of the applied sources to the plant production with no nitrogen application, there was an increase of 39,45 and $30 \%$ for $\mathrm{HHF}, \mathrm{BF}$ and urea, respectively.

The number of tillers presented a linear positive fit for all evaluated sources (Fig. 2B). With the use of HHF, the plants presented an increase of 0.05 tiller pot ${ }^{-1}$ to each kilo of applied nitrogen, reaching 35 tillers pot $^{-1}$ at the dose of 400 $\mathrm{kg} \mathrm{ha}^{-1}$ of $\mathrm{N}$. The BF source promoted an increase of 0.07 tiller pot $^{-1}$ per kilo of $\mathrm{N}$ applied, with the production of 46 tillers pot ${ }^{-1}$ in the highest evaluated dose $\left(400 \mathrm{~kg} \mathrm{ha}^{-1}\right)$. Urea promoted increased LA of 0.1 tiller pot ${ }^{-1}$ per $\mathrm{kg}$ of $\mathrm{N}$ applied, with the production of 65 tillers pot $^{-1}$ at the dose of $400 \mathrm{~kg}$ $\mathrm{ha}^{-1}$.

The chlorophyll content presented adjustment to the linear positive model for all the evaluated sources (Fig. 2C). The plants presented values of 27, 32 and 35 ICF for HHF, BF and urea, respectively.

When comparing to the absence of nitrogen fertilization (control plants), plants presented an increase of 13, 34 and $47 \%$ for $\mathrm{HHF}, \mathrm{BF}$ and urea, respectively.

For crude protein, only the HHF source presented no adjustment to the regression model (Fig. 2C), with a mean of $8.8 \%$. BF provided an increase of $0.008 \%$ in crude protein to each kilo of $\mathrm{N}$ applied, yielding plants with $10.8 \%$ protein at the maximum evaluated dose $\left(400 \mathrm{~kg} \mathrm{ha}^{-1}\right)$. The urea source produced $11.4 \%$ protein with the highest applied dose.

The use of nitrogen sources, when compared to the absence of nitrogen fertilization, allowed an increase of 41 and $48 \%$ for BF and urea, respectively, at the dose of $400 \mathrm{~kg} \mathrm{ha}^{-1}$.

For the agronomic efficiency of nitrogen, the HHF source presented no adjustment to the regression model, with a mean of 2.25 (Fig. 2E). However, the BF and urea sources presented an adjustment to the negative linear model, with a reduction of 0.02 and 0.03 in the AEN value to each kilogram of applied $\mathrm{N}$, respectively.

Regarding forage mass, the HHF and urea sources presented an adjustment to the positive linear model, whereas the BF source did not fit the model, with an average value of 2.4 grams pot ${ }^{-1}$ of FM (Fig. 2F). 
Table 1. Chemical and physical characterization of the soil used in the experiment.

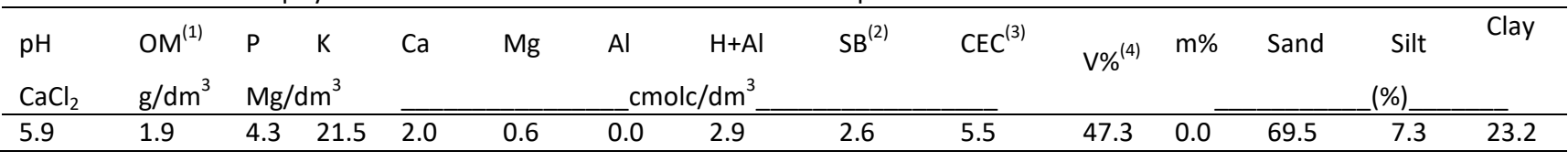

(1) OM: Organic matter; (2) SB: Sum of Bases; (3) CEC: Cation exchange capacity at pH 7.0; (4) V\%: Base Saturation.


Fig 1. Leaf area (A), number of tillers (B), chlorophyll content (C), crude protein (D), agronomic efficiency of nitrogen (E) and forage mass (F) of mombasa grass plants in relation to nitrogen doses with the following sources: hoof and horn flour (HHF), blood flour $(B F)$ and urea; Averages followed by the same letter at the doses did not significantly differ by the Tukey test $(p \leq 0.05)$.

Table 2. Chemical and physical characterization of the studied nitrogen sources.

\begin{tabular}{|c|c|c|c|}
\hline Nutrients & $\mathrm{HHF}$ & $\mathrm{BF}$ & Urea \\
\hline $\mathrm{N}$ & 124.5 & 139.0 & 450.0 \\
\hline$P$ & 2.6 & 2.5 & _ \\
\hline K & 35.0 & 6.6 & - \\
\hline $\mathrm{Ca}$ & 2.6 & 8.7 & - \\
\hline $\mathrm{Mg}$ & 0.6 & 0.2 & - \\
\hline$S$ & 2.4 & _ & - \\
\hline $\mathrm{Zn}$ & 115.0 & 20.0 & - \\
\hline $\mathrm{Mn}$ & 23.0 & - & - \\
\hline $\mathrm{Fe}$ & 731.0 & 930.0 & - \\
\hline $\mathrm{Cu}$ & 12.0 & 20.0 & - \\
\hline
\end{tabular}



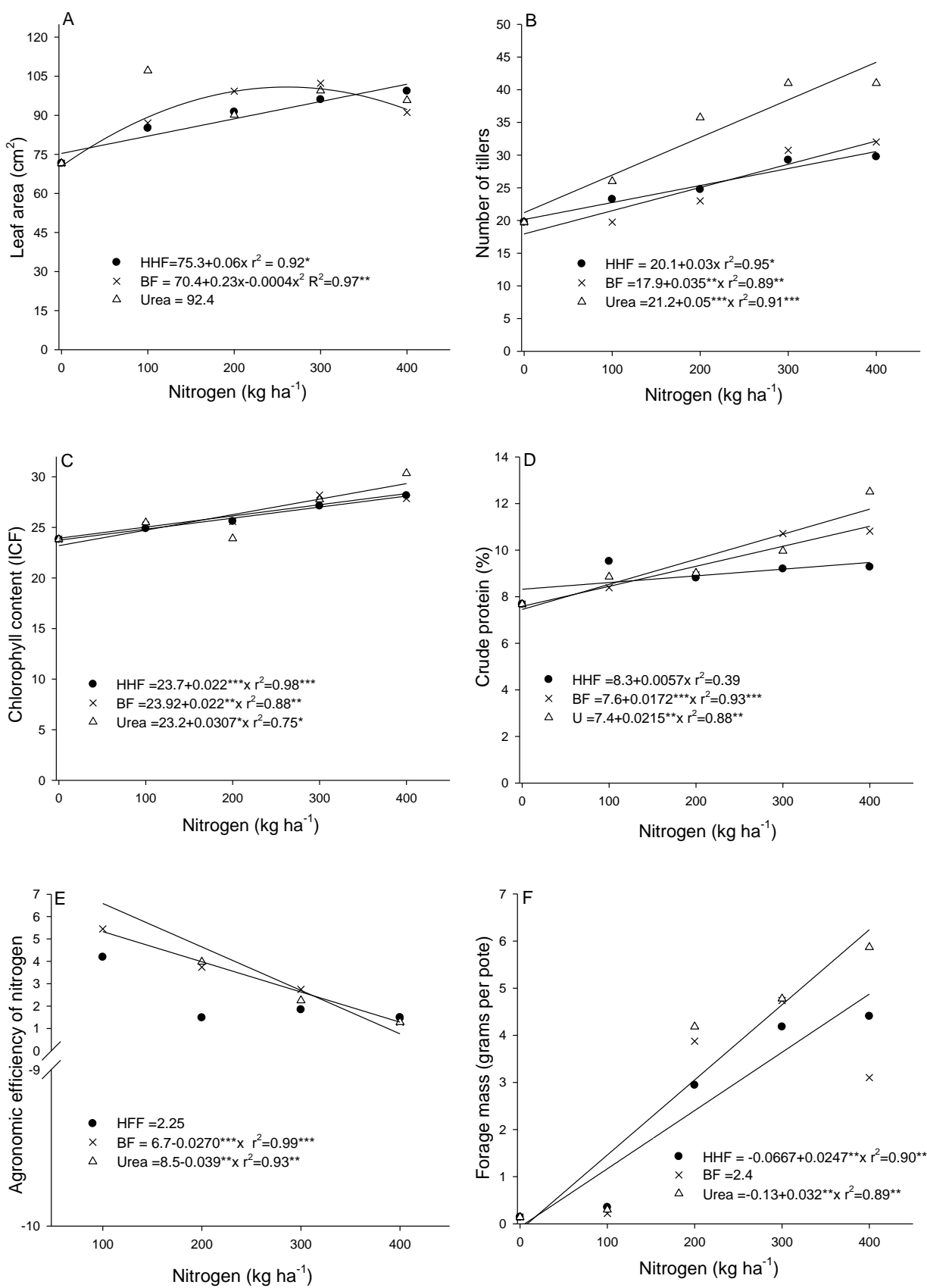

Fig 2. Leaf area (A), number of tillers (B), chlorophyll content (C), crude protein (D), agronomic efficiency of nitrogen (E) and fo rage mass (F) of mombasa grass plants in relation to nitrogen fertilization with the following sources: hoof and horn flour (HHF), blood flour (BF) and urea.

With the use of the HHF source, an increase of $0.012 \mathrm{~g} \mathrm{pot}^{-1}$ was added to each kilo of $\mathrm{N}$ applied, producing plants with $\mathrm{FM}$ of 4.74 grams of pot $^{-1}$ at the dose of $400 \mathrm{~kg} \mathrm{ha}^{-1}$. Urea presented a behavior similar to HHF, yielding $0.015 \mathrm{~g} \mathrm{pot}^{-1}$ to each kilo of applied $\mathrm{N}$, generating plants with $5.9 \mathrm{~g} \mathrm{pot}^{-1}$ at the highest evaluated dose $\left(400 \mathrm{~kg} \mathrm{ha}^{-1}\right)$.

\section{Discussion}

Studies have proven the influence of the nutritional status of the forage plant on tillering and other morphological attributes, such as leaf area (Lavres Jr and Monteiro, 2003).
The results showed that the alternative sources $\mathrm{HHF}$ and $\mathrm{BF}$ positively influenced the evaluated attributes in mombasa grass plants. Additionally, Demattê et al. (2016), show that there is a significant nutrient $(\mathrm{C}, \mathrm{N}, \mathrm{P}, \mathrm{Ca}, \mathrm{Mg}, \mathrm{K}, \mathrm{Na}$, and $\mathrm{S})$ increase.

The increase of mass in the cultivated area depends on the development of leaf area (Pedreira and Pedreira, 2007), by applying urea and the alternative sources ( $\mathrm{HHF}$ and $\mathrm{BF}$ ), it was possible to promote higher LA for the mombasa grass plants when compared to the control plants that did not receive any nitrogen. 
According to the regression graph for the number of tillers (Fig. 2B), regardless of the nitrogen source, there was an increase in the number of tillers as the nitrogen dose increased. These results demonstrate the efficiency of the alternative sources for this variable and corroborate with the results found by Benett et al. (2008), who mentioned that nitrogen is one of the main nutrients to provide better tillering and plant production.

Organic fertilizers, such as the studied sources, when compared to mineral fertilizers, such as urea, have a slower mineralization rate. However, they imply a longer effect of constant availability of the nutrients to the plant, favoring its development over several cycles (Silva et al., 2013).

Practical solutions for soil conservation and maintenance or improved crop productivity are needed to ensure sustainable food production (Ranaivoson et al., 2017). It is estimated that the Brazilian cattle production is mostly derived from pasture production (Carneiro et al., 2017). With these results, it was possible to increase the production of mombasa grass plants (Fig. 1), which was similar to the use of nitrogen fertilizer, promoting a suitable and sustainable destination for wastes with low or no economic value (eg.: HHF and BF). For Demattê et al. (2016), if properly used, slaughterhouse residues have potential to be used as fertilizers due to their considerable amounts of nutrients.

Considering that the standard fertilization in mombasa grass is equivalent to $50 \mathrm{~kg} \mathrm{ha}^{-1}$ of nitrogen (Sousa and Lobato, 2004), with the use of $79 \mathrm{~kg} \mathrm{ha}^{-1}$ of $\mathrm{N}$, through the HHF source, it was possible to obtain similar production when compared to standard fertilization using urea (Fig. 2F). Among the main problems associated with the use of organic sources, such as slaughterhouse residues, as substitutes of commercial fertilizers applied to crops is the need for high dosages of residues (Nunes et al., 2015), usually occurring in tons. Due to the high $\mathrm{N}$ content of the alternative HHF source (12.4\%), high dosage was not required to obtain a productivity result similar to urea, making it feasible for soil application.

Considering conservative estimates that $1.0 \mathrm{~kg}$ of $\mathrm{N}$ equals to $4.5 \mathrm{~kg}$ of $\mathrm{CO}_{2}$ equivalents (Hungria et al. 2013), the substitution of standard fertilizers by one of the tested sources tested (Fig. 2F) could avoid the emission of $225 \mathrm{~kg}$ $\mathrm{ha}^{-1} \mathrm{CO}_{2}$ equivalents.

According to Dias_Filho (2014), degraded pasture is an area that drastically reduced its productive capacity, with the accumulation of biomass with ideal indicator for forage. Moreira et al. (2009) adds that the low availability of nitrogen to the forage entails a reduction in the production of forage, initiating the process of degradation. With the use of alternative sources ( $\mathrm{HHF}$ and $\mathrm{BF}$ ) in comparison to the non_use of nitrogen fertilization, there was an increase in the production of the forage grass (Fig. 2F), which could mitigate the degradation of pastures and promote the conservation of the environment.

\section{Materials and methods}

\section{Location, Climate and characterization of soil}

The study was carried out in an experimental area of the Federal University of Tocantins (UFT), at the coordinates $11^{\circ} 44^{\prime} 44^{\prime \prime} S$ and 49o $03^{\prime} 04^{\prime \prime} \mathrm{W}$, in Gurupi. The region is classified as Brazilian Cerrado, and presents a Aw climate (hot and humid), according to the Köppen International Classification (Alvarez et al., 2013).

The research was carried out under the greenhouse $(4 \mathrm{~m}$ wide $\times 20 \mathrm{~m}$ long) covered with transparent plastic of 150 microns and with shadow sides $(50 \%$ retention capacity of the solar radiation). The experimental units consisted of plastic vessels with a capacity of $5.0 \mathrm{dm}^{3}$ and $4.0 \mathrm{dm}^{3}$ of soil was used. The soil used to fill the pots was an Oxisol (Soil Taxonomy) with Sandy Clay Loam texture (Table 1).

After soil characterization, soil acidity and fertility were corrected according to the crop demand (Sousa e Lobato 2004). The soil was incubated for 30 days at $70 \%$ of the field capacity. A randomized block design in a $4 \times 3+1$ factorial scheme with four replications was used. Four doses of nitrogen fertilization were studied $(100,200,300$ e $400 \mathrm{~kg}$ $\mathrm{ha}^{-1}$ de N) and three sources of nitrogen (Hull and horn flour, blood meal and Urea), plus a control without nitrogen fertilization. The HHF and BF residues were obtained from a slaughterhouse (COOPERFRIGU) of Gurupi _ TO, resulting from the slaughter of 600 animals. The chemical and physical characterization of all used nitrogen sources was performed (Table 2).

The studied culture was the forage Megathyrsus maximus cv. mombasa. The seeds presented a purity of $62 \%$ and germination of $82 \%$, with a cultural value of $50 \%$. Sowing was performed at the 1.0_cm depth in the proportion of 2.0 $\mathrm{g} \mathrm{pot}^{-1}$ of seeds. After ten days of emergency (DAE), plants were thinned to leave seven vigorous and well distributed plants in the surface area of the pot. The application of the nitrogen sources was divided in three times during the four harvests.

\section{Analyzed variables}

The following variables were evaluated: leaf area, number of tillers, chlorophyll content, crude protein, agronomic efficiency of nitrogen and forage mass.

The leaf area (LA) was calculated from the measurement of the height $x$ width of the leaf in $\mathrm{cm}$, considering six leaves per pot. The average data was based on the formula proposed by Benincasa (2003):

$$
\mathrm{LA}=\mathrm{H} \times \mathrm{W} \times 0.905
$$

Where: $\mathrm{H}=$ mean height; $\mathrm{W}=$ mean width.

The number of tillers (NT) was obtained by simple counting. The forage was harvested at a height of $30 \mathrm{~cm}$ from the soil level in the pot. After the cut, the material was packed in paper bags and oven dried at $60 \stackrel{\circ}{ } \mathrm{C}$ for 72 hours to obtain the forage mass (FM). The forage samples, after pre_dried and ground in a $1 \mathrm{~mm}$ sieve, were subjected to sulfur digestion, distillation (Kjeldahl) and titration for the determination of the crude protein (CP). The chlorophyll content (CC) was determined using a portable digital chlorophyll meter (model CFL_1030). The agronomic efficiency of nitrogen (AEN) was calculated by formula:

$$
\mathrm{AEN}=(\mathrm{PD}-\mathrm{PA} \div \mathrm{ND}-0 \mathrm{D}) \times 100
$$

Where: PD: production in doses; PA: production in the absence of nitrogen; ND: N applied dose; OD: Dose zero.

\section{Statistical analysis}

Initially, the data were tested for normality (Shapiro_Wilk) and homoscedasticity. The $F$ test was applied for the qualitative data (nitrogen sources), and when significant, the Tukey test was applied $(p \leq 0.05)$. The quantitative data 
(nitrogen doses) were submitted to regression analysis, evaluating the significance of betas and the determination coefficients to obtain the appropriate regression model $(p \leq 0.05)$.

\section{Conclusion}

The application of the alternative sources _ hull and horn flour and blood flour _ promoted an increase in the following attributes: leaf area, number of tillers, crude protein and forage mass.

The organic sources have potential to be applied as nitrogen fertilizers in soil under pasture, promoting an environmentally adequate destination for the wastes.

The use of slaughterhouse residues promoted mitigation in the use of nitrogen fertilizer.

The use of alternative sources reduced the $\mathrm{CO}_{2}$ eq emissions by not using urea, without productivity loss.

\section{Acknowledgements}

The authors gratefully thank the Federal University of Tocantins (UFT) and the research group on organic waste (NERO) of the UFT.

\section{References}

ABIEC (2017) Livestock profile in Brazil: annual report (in portuguese). Brazilian Association of Meat Exporters. Available http://abiec.siteoficial.ws/images/upload/sumario_pt_010 217.pdf (Access February 14, 2018).

Alvarez CA, Stape JL, Sentelhas PC, Goncalves JLM, Sparovek G (2013) Koppen's climate classification map for Brazil. Meteorol Z. 22:711-728.

Amanatidou E, Samiotis G, Bellos D, Pekridis G, Trikoilidou E (2015) Net biomass production under complete solids retention in high organic load activated sludge process. Bioresour Technol. 182: 193-199.

Araujo AS, Silva JEC, Santos AC, Silva Neto SP, Dim VP, Alexandrino E (2011) Substituição de nitrogênio por esterco bovino na produtividade de forragem e qualidade do solo. Rev Bras Saúde Prod An. 12: 852_866.

Benett CGS, Buzetti S, Silva KS, Bergamaschine AF, Fabricio JA (2008) Produtividade e composição bromatológica do capim marandu a fontes e doses de nitrogênio. Ciênc Agrotec. 32: 1629_1636.

Benincasa MMP (2003) Plant Growth Analysis: Basics (in portuguese). 2 ed. Jaboticabal: FUNEP. 42p.

Bonchenari KM, Alizadeh A, Javadi L, Zohrevand M, Odongo NE, Salem AZM (2017) Use of poultry pre_cooked slaughterhouse waste as ruminant feed to prevent environmental pollution. J Clean Prod. 145: 151_156.

Canto MW, Almeida GM, Costa ACS, Barth Neto A, Scaliante Júnior JR, Orlandini CF (2016) Seed production of "Mombasa" grass subjected to different closing cut dates and nitrogen rates. Pesq Agropec Bras. 51: 766-775.

Carneiro JSS, Silva PSS, Santos ACM, Freitas GA, Silva RR (2017) Resposta do capim mombaça sob efeito de fontes e doses de fósforo na adubação de formação. J Bioen Food Sci. 4: 12_25.

Demattê JAM, Oliveira JC, Tavares TR, Lopez LR, Terra FS, Araujo SR, Fongaro CT, Maia SMF, Mello FFC, Rizzo R,
Vicente S, Bortolleto MAM, Cerqueira PHR (2016) Soil chemical alteration due to slaughterhouse waste application as identified by spectral reflectance in São Paulo State, Brazil: an environmental monitoring useful tool. Environ Earth Sci. 75:1277.

Dias_Filho MB (2014) Diagnosis of pastures in Brazil (in portuguese). Documentos 402. Belém: Embrapa Amazônia Oriental. (Documentos, 402). 36p.

Freitas GA, Chagas JFR, Melo MP, Negreiro Neto, Leite RC, Silva RR (2015) Resíduo orgânico bovino enriquecido com fontes de cálcio como corretivo da acidez do solo. GI Sci Technol. 8(3): 1-11.

Hungria M, Mendes IC, Mercante FM (2013) Biological nitrogen fixation as a low carbon technology: evaluation of bean and soybean crops. (in portuguese) Londrina: Embrapa Soja, 2013. (Documentos, 337) 22p.

Hungria M, Nogueira MA, Araujo RS (2016) Inoculation of Brachiaria spp. with the plant growth_promoting bacterium Azospirillum brasilense: An environment_friendly component in the reclamation of degraded pastures in the tropics. Agric Ecosyst Env. 221: 125-131.

Lavres Jr J. and Monteiro FA (2003) Perfilhamento, Área foliar e sistema radicular do capim_mombaça submetido a combinações de doses de nitrogênio e potássio. R Bras Zootec. 32(5): 1068_1075.

Morais RF, Quesada DM, Reis VM, Urquiaga S, Alves BJR, Boddey RM (2012) Contribution of biological nitrogen fixation to elephant grass (Pennisetum purpureum Schum.). Plant Soil. 356: 23-34.

Moreira LM, Martuscello JA, Fonseca DM, Mistura C, Morais RV, Ribeiro Júnior Jl (2009) Perfilhamento, acúmulo de forragem e composição bromatológica do capim_braquiária adubado com nitrogênio. R Bras Zootec. 38(9): 1675_1684.

Nunes WAGA, Menezes JFS, Benites VM, Lima Junior SA, Oliveira AS (2015) Use of organic compost produced from slaughterhouse waste as fertilizer in soybean and corn crops. Sci Agric. 72(4): 343_350.

Pedreira BC and Pedreira CGS (2007) Fotossíntese foliar do capim_xaraés [Brachiaria brizantha (A. Rich.) Stapf. cv. Xaraés] e modelagem da assimilação potencial de dosséis sob estratégias de pastejo rotativo. R Bras Zootec. 36(4); 773_779.

Pereira EL, Paiva TCB, Silva FT (2016) Physico_chemical and Ecotoxicological Characterization of Slaughterhouse Wastewater Resulting from Green Line Slaughter. Water Air Soil Pollut. 227:199.

Ranaivoson L, Naudin K, Ripoche A, Affholder F, Rabeharisoa L, Corbeels M (2017) Agro_ecological functions of crop residues under conservation agriculture. A review. Agron Sustain. Dev. 37:26.

Silva LVBD, Lima VLA, Silva VNB, Sofiatti V, Pereira TLP (2013) Torta de mamona residual e irrigação com efluente sobre crescimento e produção de algodoeiro herbáceo. R Bras Eng Agríc. Ambiental. 17(12): 1264_1270.

Sousa DMG and Lobato E (2004) Savanna: Soil correction and fertilization (in portuguese). Brasília: Embrapa Informação Tecnológica, $416 \mathrm{p}$.

Zwetsloot MJ, Lehmann J, Solomon D (2014) Recycling slaughterhouse waste into fertilizer: how do pyrolysis temperature and biomass additions affect phosphorus availability and chemistry?. J Sci Food Agric. 95: 281_288. 